\section{Soils and Soil Management}

By Prof. A. F. Gustafson. (MeGraw-Hill Publications in the Agricultural Sciences.) Pp. viii +424. (New York and London: MeGraw-Hill Book Co., Inc., 1941.) $21 s$.

$\mathrm{T}$

HIS book sets out to describe the principles of soil management from a practical point of view in a way that should be intelligible to the modern farmer or to students taking advanced courses in agricultural colleges. The author covers the whole field of soil management including, on one hand, zuch subjects as soil cultivation, erosion control, dry arming and irrigation and, on the other, fertilizers, nanures and crop rotation. He naturally chooses nost of his examples from the United States and iends to emphasize points of importance to that zountry, but this restriction does not detract from the book's educational value for students outside that country, although some of the detail will naturally not apply.

The main criticism of the book is that the scientific principles underlying the practice are not always clearly brought out. This is especially unfortunate in those subjects in which there is no traditional background of knowledge to help the reader pick out those particular details of practice that would be applicable outside the agricultural regions described. A minor criticism is that the introductory chapters on what is often called soil science, namely, soil formation, soil micro-organisms, soil organic matter and soil water are too sketchy to be really helpful, and, in addition, that on soil water is not up to date. The main part of the book, on soil management proper, does not suffer from this latter defect. The subjects are treated fully, particularly on the practical side, and the text is illustrated with a large number of well-chosen figures.

E. W. R.

\section{The Riddle of Religious Education and a $\mathrm{New}$ Solution}

By Adam Gowans Whyte. (Thinker's Forum, No. 22.) Pp. 48. (London: Watts and Co., Ltd., 1942.) $6 d$. net.

IN the course of an article which appeared in 1 NATURE of November 14 last, the position was maintained that the omission from the religious instruction of serior pupils of all reference to faiths other than the Christian would be hard to justify in these times. Mohammedans and Buddhists, Hindus and Parsees, Jews and other non-Christians, are fighting on our side in a war of good against evil-a struggle for a way of life which for many of us, but not for any of them, finds its historical expression in the New Testament. This position is very strongly maintained in Mr. A. G. Whyte's ably and vigorously written pamphlet. The body of the pamphlet is devoted to a brief historical review of all that has led up to the "dual system" of control. The writer makes some apposite quotations from eminent Churchmen who have been quite unhappy about the working of that system. His "new solution" goes all out for making religious instruction broader and more objective. He maintains that a fraction of the time spent during a child's school life in expounding the details of the Christian creeds would suffice to convey an intelligent appreciation of the fundamentals of other creeds, and to engender a more sympathetic attitude towards the millions who share our essential aims.

\section{Annual Reports on the Progress of Chemistry} for 1941

Vol. 38. Pp. xxxii+326. (London : Chemical

Society, 1942.) 15s.

T would be unprofitable to attempt to crystallize 1 an already highly concentrated essence, and indeed all that is required is a reminder that these valuable reports continue to appear without interruption. Work on diamagnetism in recent years is summarized with special reference to its relation to problems of molecular structure, and developments in the chemistry of the carbonyls and nitrosyls since 1934 are surveyed. A comprehensive report on organic chemistry deals with physico-organic topics, organometallic compounds, polysaccharides, synthetic polyenes, polyterpenes, natural quinone pigments, and heterocyclic compounds. That on crystallography relates to temperature effects in the reflexion of X-rays from crystals, and to metal, inorganic, and organic structures. Among the biochemical subjects discussed are the vitamins, particularly their assay, since it is now recognized that definite minimal quantities are needed to prevent deficiency diseases, and larger quántities to prevent subclinical deficiencies. In view of war-time restriction on the importation of fruits, the incidence of vitamin $\mathrm{C}$ in raw and prepared green vegetables is of special interest. Another topic is the utilization of carbon dioxide by bacteria and animal tissues. Analytical methods are reviewed, and the book closes with a chapter on radioactivity and sub-atomic phenomena, in which a historical introduction is followed by a survey of present knowledge of nuclear processes and of the concepts used in explaining and predicting them.

Reports of the Progress of Applied Chemistry Issued by the Society of Chemical Industry. Vol. 26, 1941. Pp. 545. (London: Society of Chemical Industry, 1942.)

WXCEPT for an additional short section on starches, E the chapters of this report correspond to those of the immediately preceding volume in the series. Vast as is the field surveyed, there can be no doubt that real progress is substantially greater, for much valuable information is necessarily being withheld from publication during the War. Many of the subjects discussed find emphasis, if not their origin, in the special demands of war-time needs; in this class are, for example, the manufacture of butadiene for synthetic rubber, substitute materials for ceramic products and the use of commoner in place of relatively rarer metals (as in the substitution of aluminium by zinc or tin-zinc alloy for milk-bottle caps). The section on plastics continues to reflect great interest and noteworthy progress, with an evermore complete fusion of "academic" and "technological" research. The supply of glycerin from soap manufacture can now be supplemented by its synthesis from propylene by way of allyl alcohol; and the physical properties of soaps and their solutions continue to attract much attention. In the section on sanitation and water purification there is reference to fluorosis arising from fluorine in drinking water: and there is quoted evidence that the incidence of goitre does not correspond to the iodine or the fluorine content of the water but may be of fungal origin. The year in review was marked by the pooling of research resources by five important drug manufacturers in Great Britain. 